Limnological Review 10, 1: 43-56

DOI 10.2478/v10194-011-0006-4

\title{
Seasonal variability in phosphorus concentrations in strongly eutrophic Lake Chełmżyńskie
}

\author{
Adam Solarczyk \\ Voivodeship Inspectorate for Environmental Protection in Bydgoszcz Branch of Toruń, \\ Targowa 13/15, 87-100 Toruń, Poland, e-mail: adam.solarczyk@wios.bydgoszcz.pl
}

\begin{abstract}
The results of the monthly examinations of Lake Chełmżyńskie carried out during the vegetation periods in the years 20072009 made it possible to define seasonal variability in the concentrations of phosphorus compounds. The examinations showed that the bottom deposits constitute a considerable source of phosphates. The release of phosphates from the deposits began as early as in mid May and with the occurrence of anoxic conditions. A particularly high concentration of phosphates in the near-bottom layer was recorded in the southeast pool of the lake (max. $0.658 \mathrm{mg} \mathrm{P} \mathrm{l}^{-1}$ ). The central part of the lake showed a lower concentration of phosphates near the bottom, yet due to the partial thermal stratification of its waters, it was the main place for the transport of the bio-element to the euphotic zone. The intense transport of phosphates occurred mainly during the short periods of strong winds. The analysis of the meteorological data obtained from the Integrated Natural Environment Monitoring - Station Koniczynka prove that winds, whose mean daily velocity values exceeded $8.0 \mathrm{~m} \mathrm{~s}^{-1}$, brought about particularly intense and deep water mixing. A very significant increase in the concentration of phosphorus compounds in the epilimnion was recorded in the years 2007 and 2008, and it resulted in the violent development of phytoplankton. The results of the examinations conducted in the years 2007-2009 showed that Lake Chełmżyńskie was classified as a strongly eutrophic lake. The ecological condition of the lake was defined as poor according to the Water Framework Directive. Reclamation works including the inactivation of phosphates in the bottom deposits are indispensable in order to improve the ecological and trophic state of the lake.
\end{abstract}

Key words: phosphorus, internal loading, eutrophication, restoration, Chełmińskie Lakeland

\section{Introduction}

Phosphorus concentrations in the lakes depend upon external inflow and internal loading. The enrichment of waters with phosphorus coming from the external sources results from increasing anthropopressure in the catchment. Alongside the increasing trophy the bottom deposits become an additional source of phosphorus (e.g. Kajak 1998; Lampert and Sommer 2001; Wetzel 2001; R.J. Wiśniewski 1995). Anoxic conditions found in the deposits and near-bottom water layer also contribute to the release of phosphates (Cerco 1989). The process of phosphorus release in the water is also determined by the reaction, temperature and type of compounds in which it occurs as well as deposits structure (Kentzer 2001; R.J. Wiśniewski 1995). Molecular diffusion (Kentzer 2001) and re-suspension (R. Wiśniewski 1995) are the most essential mechanisms for the transport of phosphorus into the over-the-deposit water lay- er. The most important factor influencing the vertical transport of phosphorus in the lakes is water mixing caused by winds (Lorke and Wuest 2005). The negative influence of the internal loading of phosphorus upon the trophic state is particularly conspicuous in polymictic lakes and eutrophic lakes of poor stratification, where seasonal or permanent anoxic conditions develop during the vegetation period (Nurnberg 1994). The probability of deep mixing in the lakes during summer stratification, which enables the transport of phosphorus from the bottom deposits, is estimated by means of the Osgood Index (Osgood 1988; Cooke et al. 1993).

The objective of the research was to describe seasonal variability in phosphorus concentrations in Lake Chełmżyńskie in the years 2007-2009, and to discuss the role of phosphorus internal loading. The author paid particular attention to the influence of wind mixing upon the concentration of phosphorus in the epilimnion as well as trophic consequences. 


\section{Material and methods}

The examinations of Lake Chełmżyńskie were conducted during the vegetation season from March to October in the years 2007-2009. Due to the diversity of the lake morphometric conditions these measurements were taken at five stands (Fig. 1). During the monthly research expeditions temperature and oxygen concentrations in the vertical distribution were measured with a temperature-oxygen meter OXI 196 by WTW, and transparency with the Secchi disc. Water was sampled from the surface layer $(1 \mathrm{~m})$ and nearbottom layer ( $1 \mathrm{~m}$ above the bottom). The accredited laboratory of the Torun Branch of the Voivodeship Inspectorate for Environmental Protection in Bydgoszcz determined the concentrations of phosphates, total phosphorus (the surface layer and the near-bottom layer), nitrogen compounds and chlorophyll $a$. The analyses were carried out pursuant to the Polish Norms.

The characteristics of the selected meteorological parameters (air temperature, wind directions and velocities) were presented on the grounds of the data registered at the meteorological station of the
Integrated Natural Environment Monitoring in Koniczynka. This station is located approximately $11 \mathrm{~km}$ to the southeast of Lake Chełmżyńskie. Very similar environmental conditions prevail in the vicinity of the station and Lake Chełmżyńskie, therefore, the meteorological data recorded in Koniczynka were assumed representative of the study area.

\section{Study area}

Lake Chetmżyńskie. Lake Chełmżyńskie is located in the central part of the Chełmińskie Lakeland. As for the genesis it is a channel lake with a long axis running from the northwest to the southeast (Niewiarowski 1959). In the central part of the lake the bottom configuration is poorly diversified, and the biggest depth does not exceed $13 \mathrm{~m}$. The maximum depth is in the southwest pool of the lake. The basic morphometric data are presented in Table 1. The high value of the exposure index proves considerable influence of climatic factors upon the shape of the water mass dynamics of Lake Chełmżyńskie.

With respect to hydrography, the studied lake is located in the drainage area of the River Fryba. The

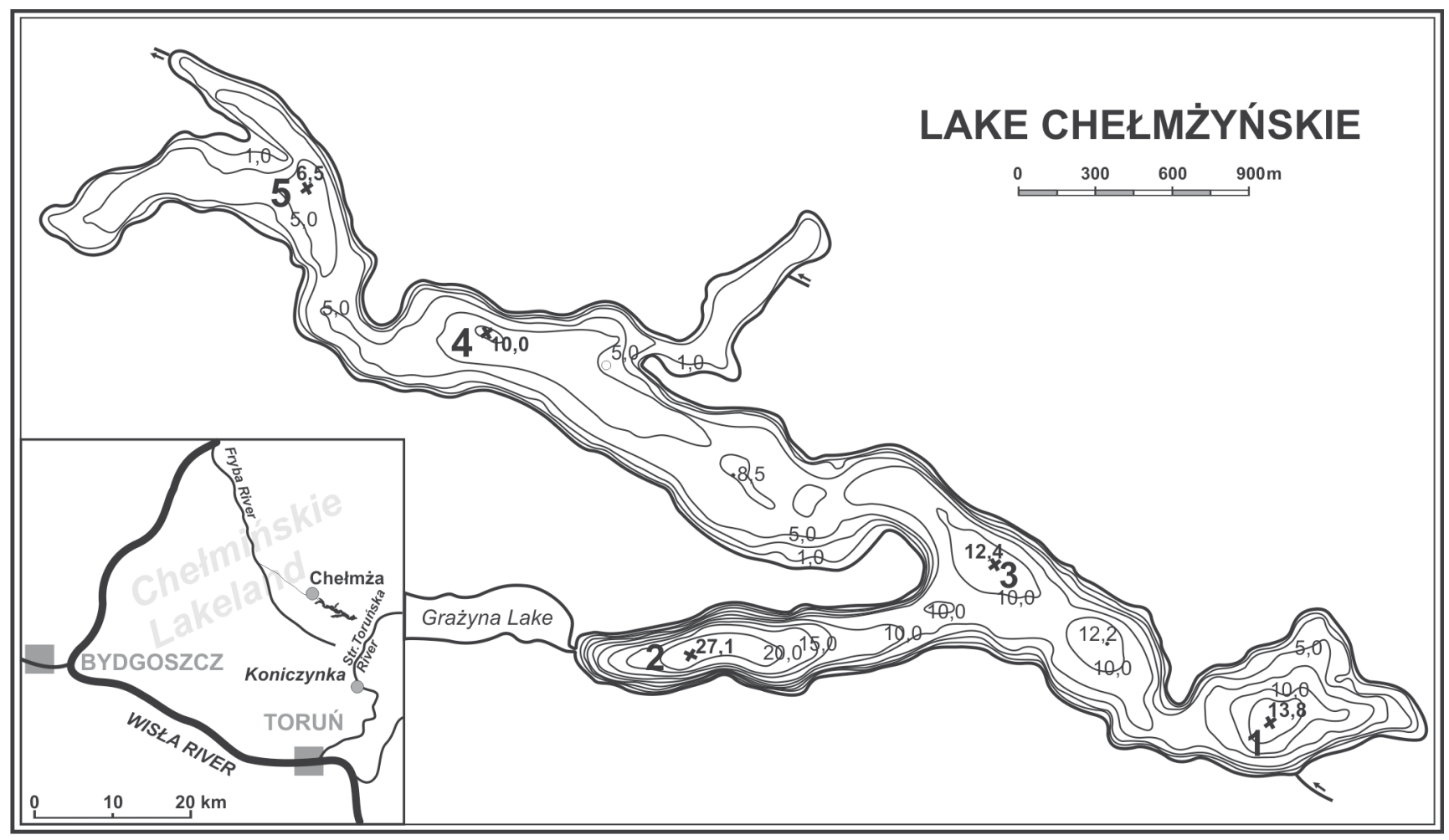

Fig. 1. Location and bathymetric map of Lake Chełmżyńskie (according to Institute of Inland Fisheries in Olsztyn, 1958) 
Table 1. Basic morphometric properties of Lake Chełmżyńskie (1-8 according to Institute of Inland Fisheries in Olsztyn, 1958; 9-10 the author's calculations)

\begin{tabular}{|l|c|c|}
\hline No & Parameters & Value \\
\hline 1 & Surface area $\left(\mathrm{A}_{0}\right)(\mathrm{ha})$ & 271.1 \\
\hline 2 & Maximum depth $(\mathrm{m})$ & 27.1 \\
\hline 3 & Volume (thous. $\left.\mathrm{m}^{3}\right)$ & 16451.9 \\
\hline 4 & Mean depth $(\mathrm{z})(\mathrm{m})$ & 6.1 \\
\hline 5 & Maximum length $(\mathrm{m})$ & 6125 \\
\hline 6 & Maximum width $(\mathrm{m})$ & 550 \\
\hline 7 & Maximum effective length $(\mathrm{m})$ & 3250 \\
\hline 8 & Maximum effective width $(\mathrm{m})$ & 515 \\
\hline 9 & Exposure index * & 44.4 \\
\hline 10 & Osgood index ** & 3.7 \\
\hline
\end{tabular}

${ }^{*} \mathrm{~A}_{0} / \mathrm{z}\left(\mathrm{A}_{0}\right.$ in ha $){ }^{* *} \mathrm{z} / \mathrm{A}_{0}^{0.5}\left(\mathrm{~A}_{0}\right.$ in $\left.\mathrm{km}^{2}\right)$

total lake catchment covers the area of $33.8 \mathrm{~km}^{2}$ (Fig. 2). The inflow from Lake Grodzieńskie is the main and constant stream (the drainage area of the stream $14.5 \mathrm{~km}^{2}$ ) supplying Lake Chełmżyńskie. In 2007 the mean discharge of the flow in the period May-October amounted to $17 \mathrm{l} \mathrm{s}^{-1}$. The total catchment area of Lake Chełmżyńskie is used mainly for farming (Fig. 2,
Table 2. Basic properties defining the total catchment of Lake Chełmżyńskie

\begin{tabular}{|l|c|c|}
\hline No & Parameters & Value \\
\hline 1 & Catchment area $\left(\mathrm{km}^{2}\right)$ & 33.8 \\
\hline 2 & Land use in the catchment & approx. $90 \%$ of farmland \\
\hline 3 & Schindler index & 2.05 \\
\hline 4 & Intensity of water exchange & 0.3 \\
\hline
\end{tabular}

* outflow/lake volume

Tab. 2). In its west part there are buildings of the town of Chełmża. In the twentieth century the lake was the major source of water used for production purposes in the Sugar Plant in Chełmża and the receiver of the spent cooling waters. At that time the lake had unfavourable water balance and in order to improve its condition water was taken from the stream Struga Toruńska (Jureko 1969). Excessive intake of water caused the disappearance of outflow from the lake (Marszelewski 1998). Water pumping was stopped in the early 1990s. The operation of the closed water circulation after the construction of the water treatment plant in the Sugar Plant restricted water intake from the lake. As a result, the level of the water table gradually increased and a natural outflow from the lake re-

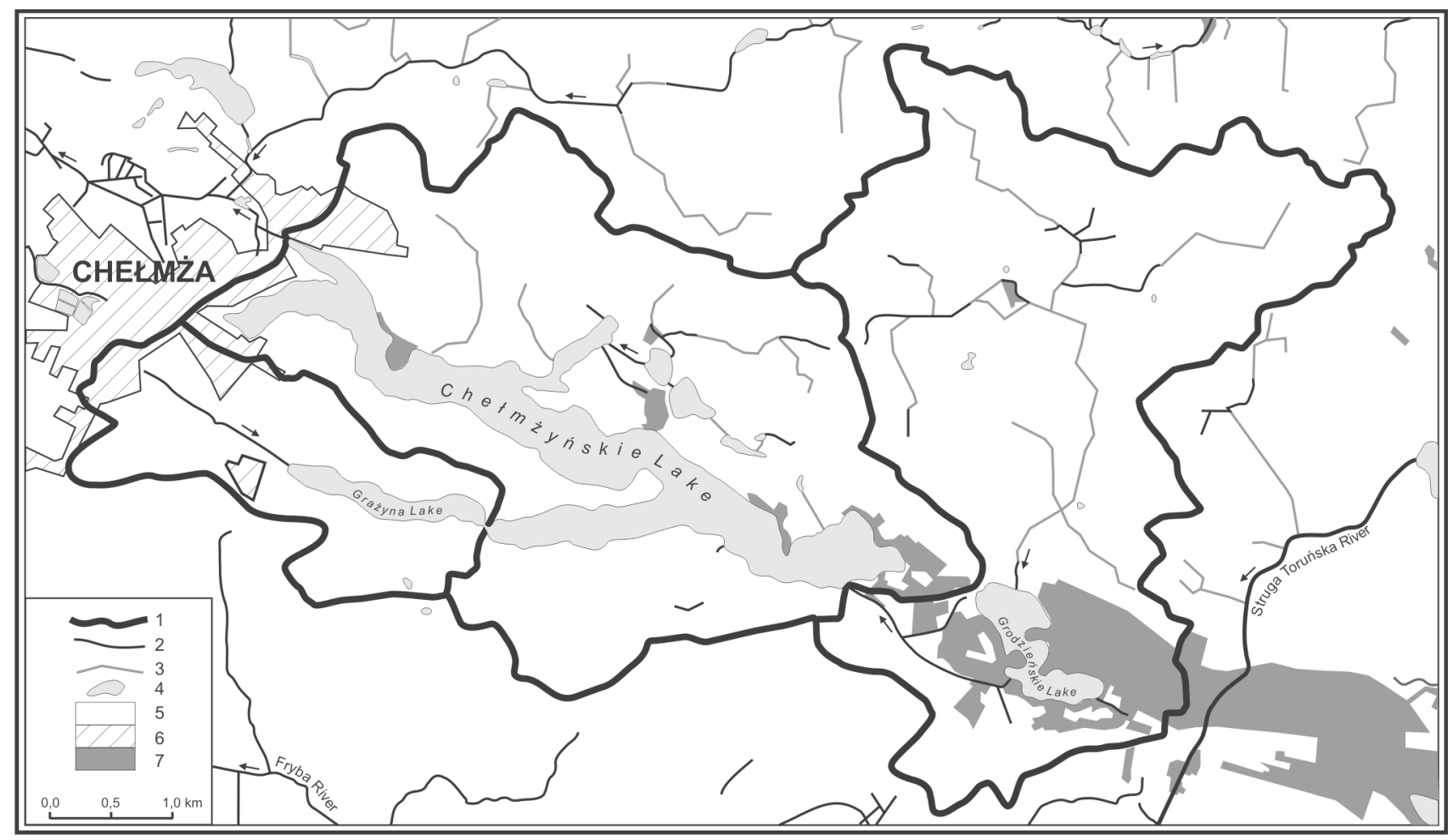

Fig. 2. Catchment of Lake Chełmżyńskie: 1 - boundaries of watersheds 2 - streams and drainage ditches 3 - drainage pipes, 4 - lakes; Land use: 5 - farm lands 6 - buildings 7 - forests 
opened. The maximum fluctuations of the water table amounted to $27 \mathrm{~cm}$ (2008) in the March-October periods in the years 2007-2009. The pace of water exchange in the lake is rather small and equals 0.3. Lake Chełmżyńskie shows a passive regime according to the hydrological typology by Pasławski (1975).

Lake Chełmżyńskie was examined three times to determine its purity state according to "The System of Water Quality Assessment” (Kudelska et al. 1994). According to this classification, the quality of the waters of Lake Chełmżyńskie stayed outside the class in 1993 , yet it corresponded to the third class of purity in 2000 and 2006 (WIOŚ 2007). Since 2007 the lake has been subject to the quality assessment pursuant to the Water Framework Directive. The results of the examinations conducted in the years 2007-2008 showed that the ecological condition of Lake Chełmżyńskie was poor (WIOŚ 2009).

As far as the trophic state is concerned, Lake Chełmżyńskie is a strongly eutrophic lake. The values of TSI (Carlson 1977) chlorophyll $a$ ranged from 57 to 75 at the peak of the summer stagnation in the years 1993-2009. The values of TSI TP were also high, whereas the values of TSI SD were considerably lower, particularly in the years 2000-2009 (Tab. 3).

Meteorological conditions. During the longterm period 1994-2008 the station in Koniczynka registered most frequently the winds of the western sector (Kejna 2009). In the years 2007-2008 the winds from the western directions were considerably more frequent. The strongest winds were characteristic of the most frequent directions (e.g. in 2007: W - $5.4 \mathrm{~m}$ $\mathrm{s}^{-1}$, SW - $4.9 \mathrm{~m} \mathrm{~s}^{-1}$, Kejna 2008). The comparison of the mean monthly wind velocities in the years 20072009 shows a noticeably higher value in April 2007 (Fig. 3). The statistical analysis of the mean daily wind velocities in the periods April-September showed the smallest changes in the parameter in 2008. The maxi- mum mean daily wind velocities $\left(>8.0 \mathrm{~m} \mathrm{~s}^{-1}\right)$ during the thermal stratification period (April - September) were recorded at the turn of June and July and in mid September 2007, yet only in early August in 2008 (Fig. 3). In 2009 the maximum mean daily wind velocity reached the value of $7.4 \mathrm{~m} \mathrm{~s}^{-1}$.

The mean annual air temperature values in Koniczynka were $9.3^{\circ} \mathrm{C}$ in 2007 and $9.4^{\circ} \mathrm{C}$ in 2008 , and clearly exceeded the mean value of $8.5^{\circ} \mathrm{C}$ for the period 1993-2007 (Kejna 2008). In the analysed years the higher values of air temperature were recorded in 2007, in the months March - May (Fig. 4). In 2007 July was fairly colder than usual, despite the occurrence of air temperature values exceeding $25^{\circ} \mathrm{C}\left(17.9^{\circ} \mathrm{C}\right.$, anomaly $-1.1^{\circ} \mathrm{C}$, Kejna 2008). In 2009 considerably lower air temperatures were observed in May and June (Fig. 4). On the other hand, the mean monthly air temperature value of $10.0^{\circ} \mathrm{C}$ in April was highest in the analysed period 2007-2009.

\section{Results and discussion}

The conducted examinations indicated the diverse course of thermal conditions prevailing in the lake in the particular years (Fig. 5). The temperature values of the near-bottom water layers at the deepest stand 2 in the years $2007-2009\left(5.3-7.5^{\circ} \mathrm{C}\right)$ showed that the thermal stratification occurred earliest in 2009.

In the analysed years, April 2009 showed the highest air temperature and the lowest wind velocity values (Fig. 3, Fig. 4). The high air temperatures prevailing in late May 2007 caused that the maximum thermal gradients developed at the depth of 3-4 m. The thermal profiles at the stand 1 and 2 indicate that the metalimnion was initially found at the depth of $9.0 \mathrm{~m}$ (Fig 5). In the years 2008 and 2009 the values of the thermal gradients were lower, and moreover, they occurred at greater depths (5-6 m in 2008 and 8-12 m

Table 3. The values of basic trophic indexes in Lake Chełmżyńskie during the summer stagnation (July/August) in the years 1993-2009 (according to the Voivodeship Inspectorate for Environmental Protection in Bydgoszcz)

\begin{tabular}{|c|c|c|c|c|c|c|}
\hline Year & $\begin{array}{c}\text { Chlorophyll a } \\
\qquad\left(\mu \mathrm{g} \mathrm{I}^{-1}\right)\end{array}$ & $\begin{array}{c}\text { TP } \\
\left(\mu \mathrm{g} \mathrm{I}^{-1}\right)\end{array}$ & $\begin{array}{l}\text { SD } \\
(\mathrm{m})\end{array}$ & TSI Chl & TSI TP & TSI SD \\
\hline 1993 & 88.70 & 30 & 0.6 & 75 & 53 & 67 \\
\hline 2000 & 38.30 & 48 & 1.5 & 66 & 60 & 54 \\
\hline 2006 & 15.50 & 50 & 1.6 & 57 & 61 & 53 \\
\hline 2007 & 40.36 & 123 & 1.5 & 67 & 74 & 54 \\
\hline 2008 & 32.24 & 59 & 1.7 & 65 & 63 & 52 \\
\hline 2009 & 34.64 & 104 & 2.1 & 65 & 71 & 49 \\
\hline
\end{tabular}



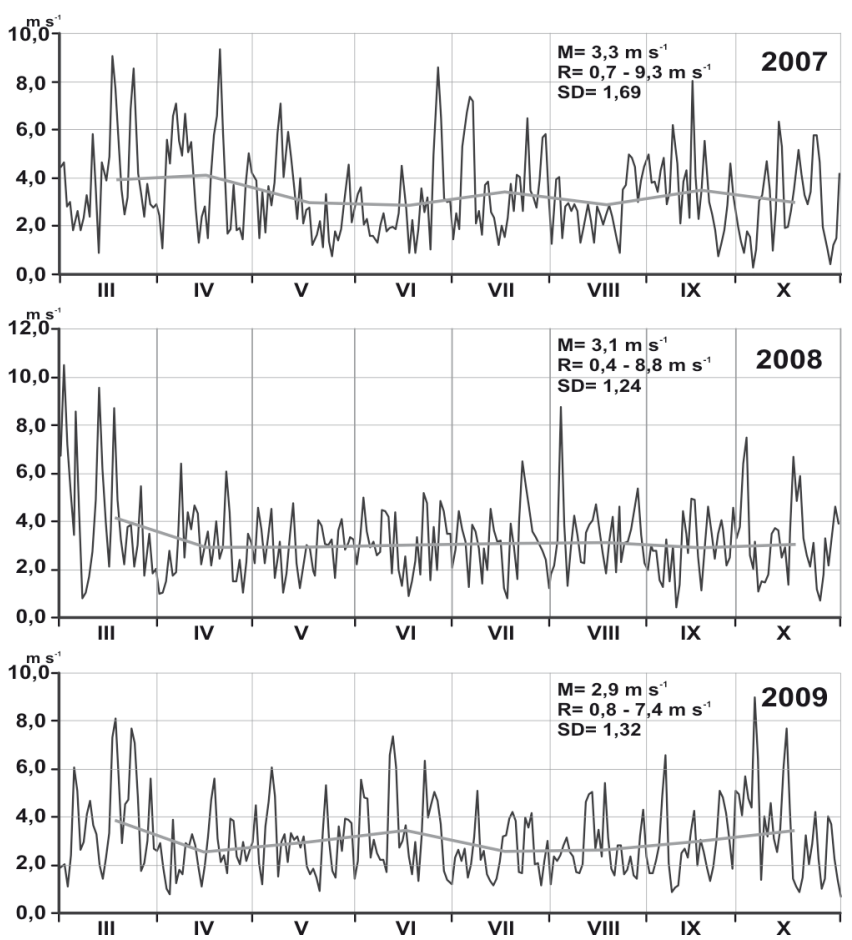

Fig. 3. Mean daily and monthly wind velocities in Koniczynka in the years 2007-2009 (on the grounds of unpublished materials). Mean (M), ranges (R) and standard deviations (SD) given for the period April-September

in 2009). The earliest changes in the maximum values of the thermal gradients and their depths occurred at the beginning of July in 2007. Whereas, in 2008 the erosion of the metalimnion was recorded at the end of July. In 2009 the maximum thermal gradients were recorded in the period from May to August at the constant depth (8-12 $\mathrm{m}$ in May, 9-13 $\mathrm{m}$ in early August). In the period from the end of May to the turn of July and August the highest temperature values of the near-bottom water layers were recorded at the stands 3 and 4 in the years 2007 and 2009 (Fig. 5).

The pace of depletion of oxygen resources in Lake Chełmżyńskie was very fast because severe oxygen deficits were noted as early as in late May. There were also anoxic conditions (Fig. 6). In the subsequent months the deoxygenated layer covered not only the hypolimnion but also it was present in the metalimnion. Furthermore, the epilimnion clearly revealed oxycline (e.g. July 2008 and August 2009). At the turn of June and July in the years 2007 and 2008 the deoxygenated zone comprised the layers of water below the depth of $7.0 \mathrm{~m}$ and $9.0 \mathrm{~m}$. Whereas in 2009 a similar extent of this layer was observed as late as during the
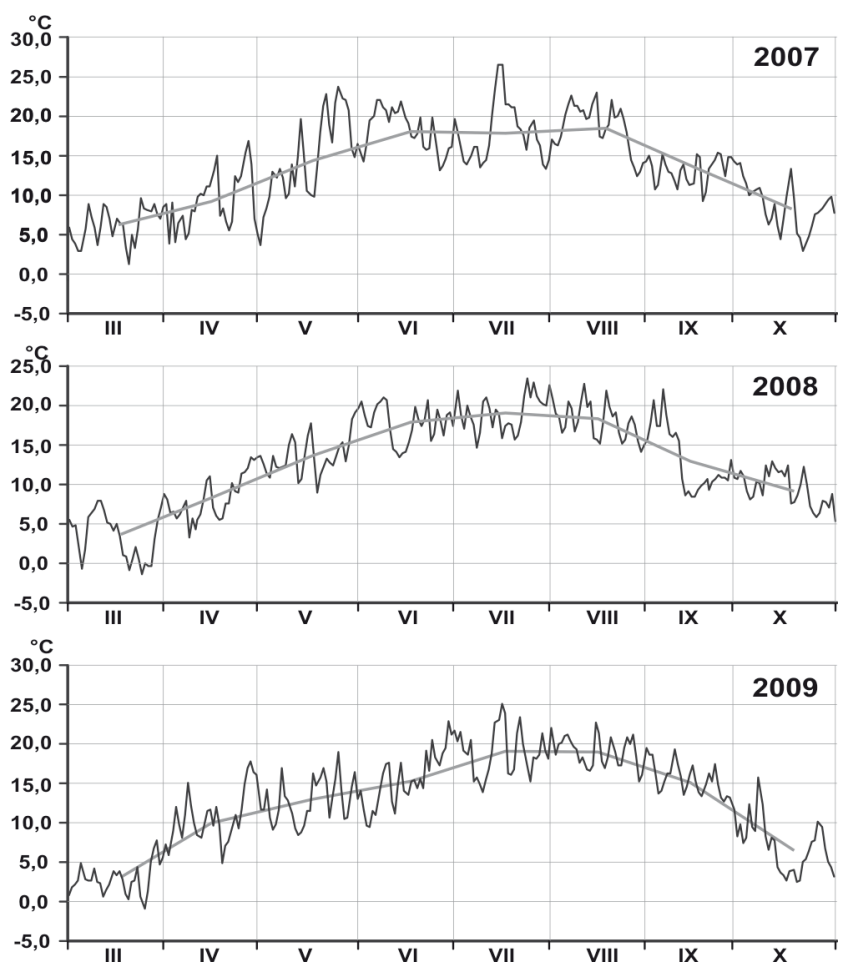

Fig. 4. Mean daily and monthly air temperature in Koniczynka in the years 2007-2009 (on the grounds of unpublished materials)

examinations carried out at the beginning of August. During its maximum extent (the turn of July and $\mathrm{Au}-$ gust) the anoxic zone covered approximately $35 \%$ of the area of the bottom of Lake Chełmżyńskie.

The mean concentration of total phosphorus in the surface layers during the vegetation seasons (March - October) in the period 2007-2009 stayed similar in the particular study years, and did not exceed $0.100 \mathrm{mg} \mathrm{P}^{-1}$ (Fig. 7). There were no significant differences in phosphorus concentrations at the particular examination stands, however, its concentration varied seasonally, e.g. in April 2009 (the range from 0.041-0.097 $\mathrm{mg} \mathrm{P} \mathrm{l}^{-1}$ ) and in August 2008 (0.124$\left.0.195 \mathrm{mg} \mathrm{P} \mathrm{l}^{-1}\right)$. The concentration of phosphates in the surface layer fluctuated in the study period from the value lower than the marking $\left(0.005 \mathrm{mg} \mathrm{P} \mathrm{l}^{-1}\right)$ to $0.101 \mathrm{mg} \mathrm{P} \mathrm{l}^{-1}$ (October 2009, Fig. 8). The portion of phosphates in total phosphorus in the surface layer of the lake in the months July - September amounted to $57 \%$ at maximum.

The concentration of total phosphorus and phosphates in the near-bottom layer of the lake was highest at the stand 1 in all the studied years (Fig. 9). The con- 

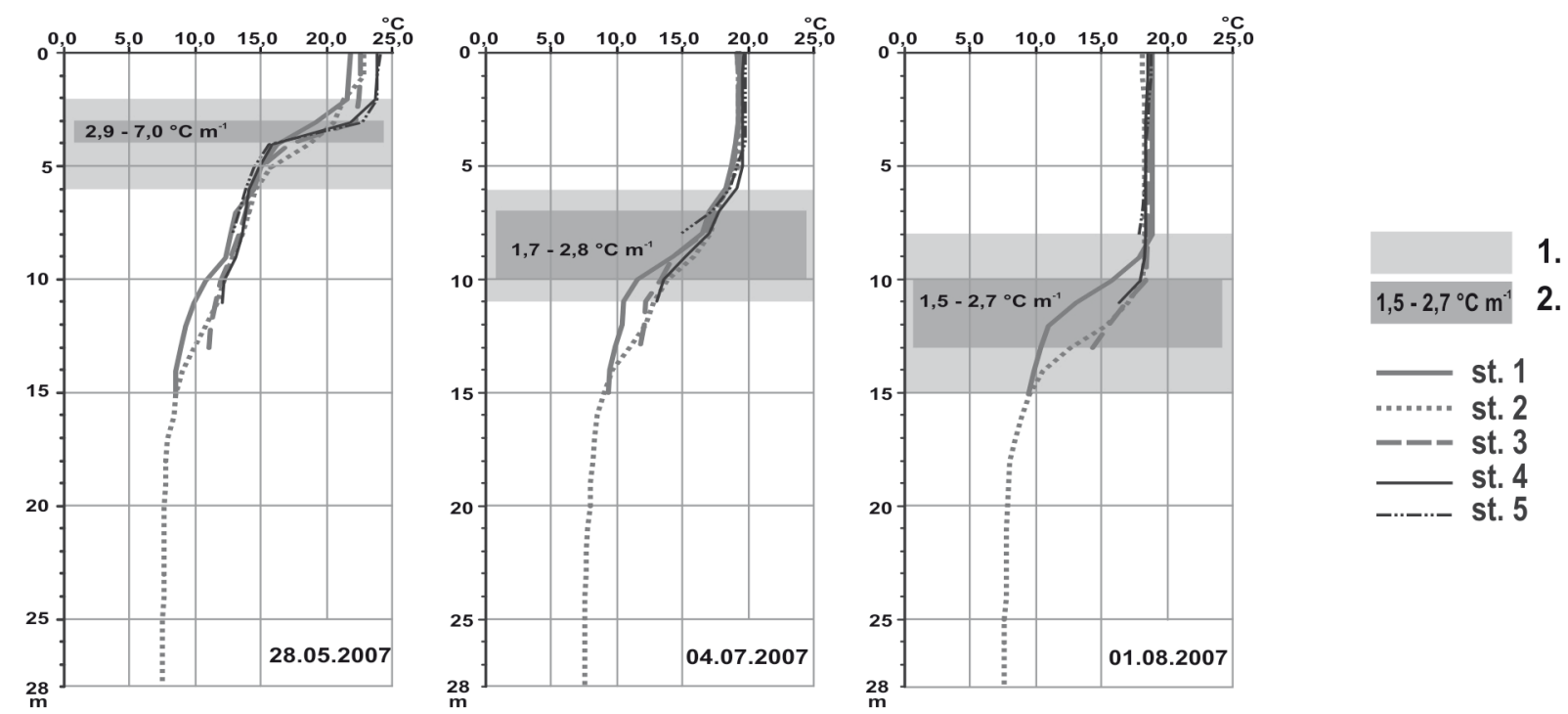

1.

st. 1

......... st. 2

- - st. 3

st. 4

-..... st. 5

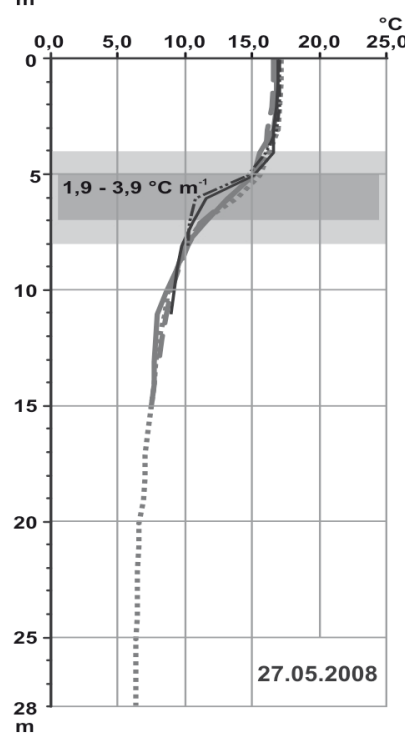

\begin{tabular}{llllll}
0,0 & 5,0 & 10,0 & 15,0 & 20,0 & ${ }^{\circ} \mathrm{C}$ \\
\hline
\end{tabular}
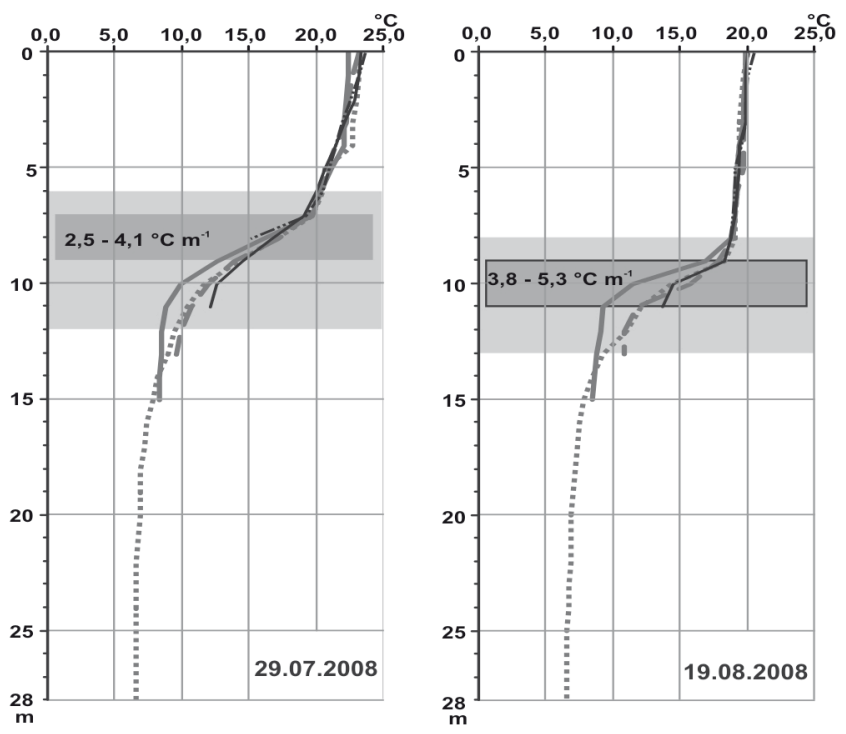

$\begin{array}{llllll}0,0 & 5,0 & 10,0 & 15,0 & 20,0 & { }^{\circ} \mathrm{C}\end{array}$
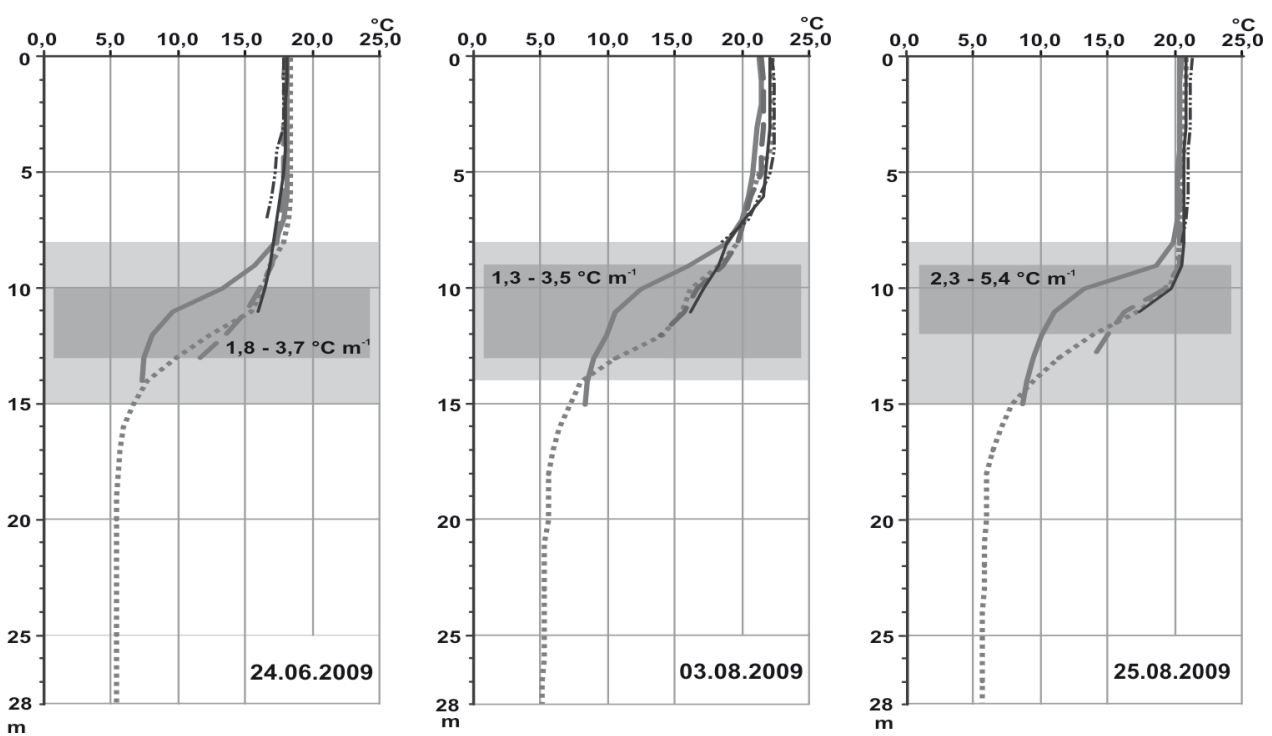

m

19.05.2009

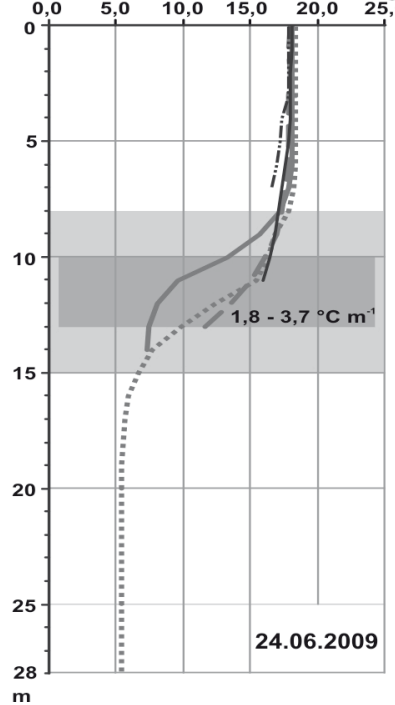

Fig. 5. Thermal profiles of Lake Chełmżyńskie in the years 2007-2009: 1 - the extent of the metalimnion, 2 - the extent of maximum thermal gradients 

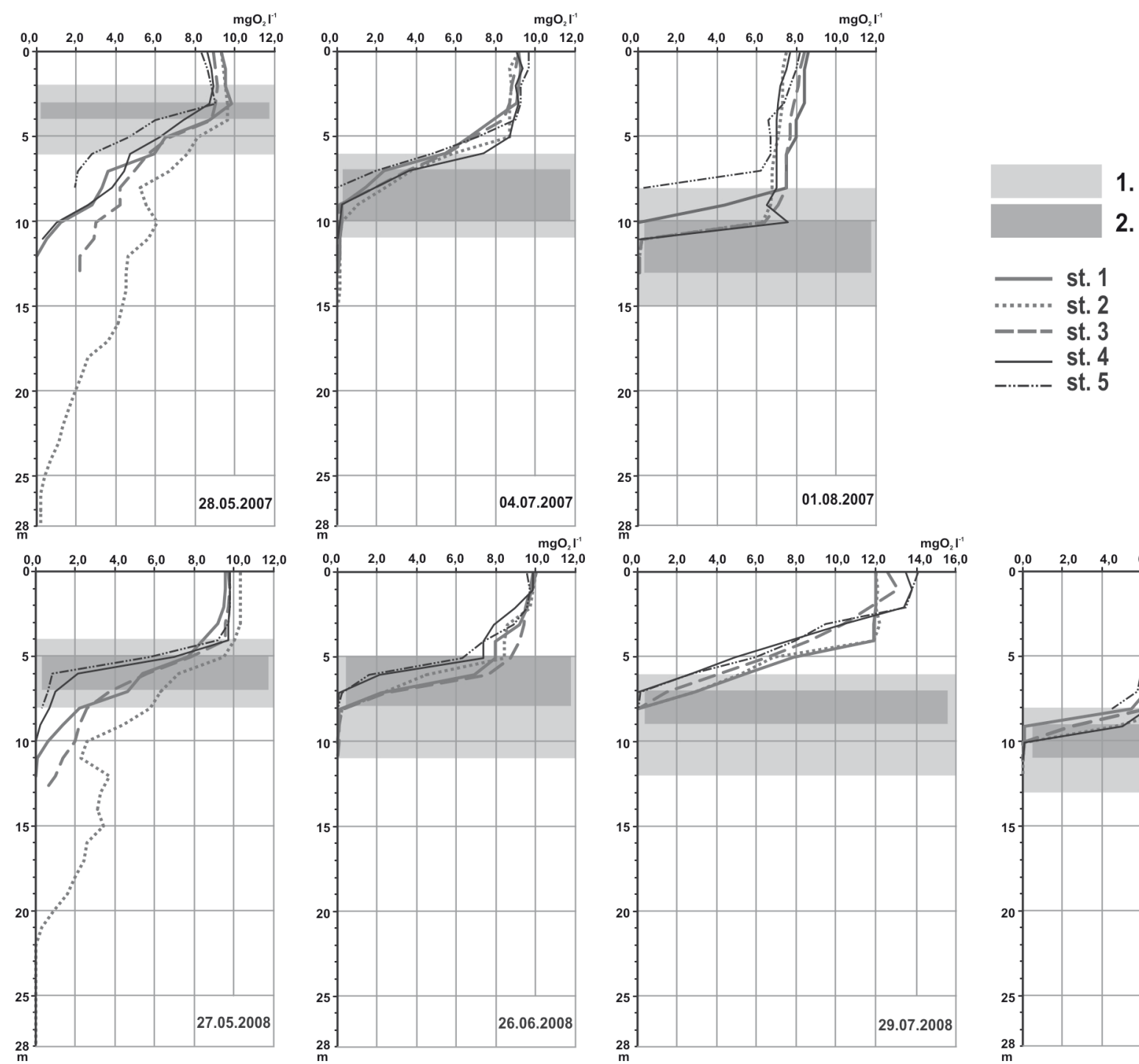

1.

2.
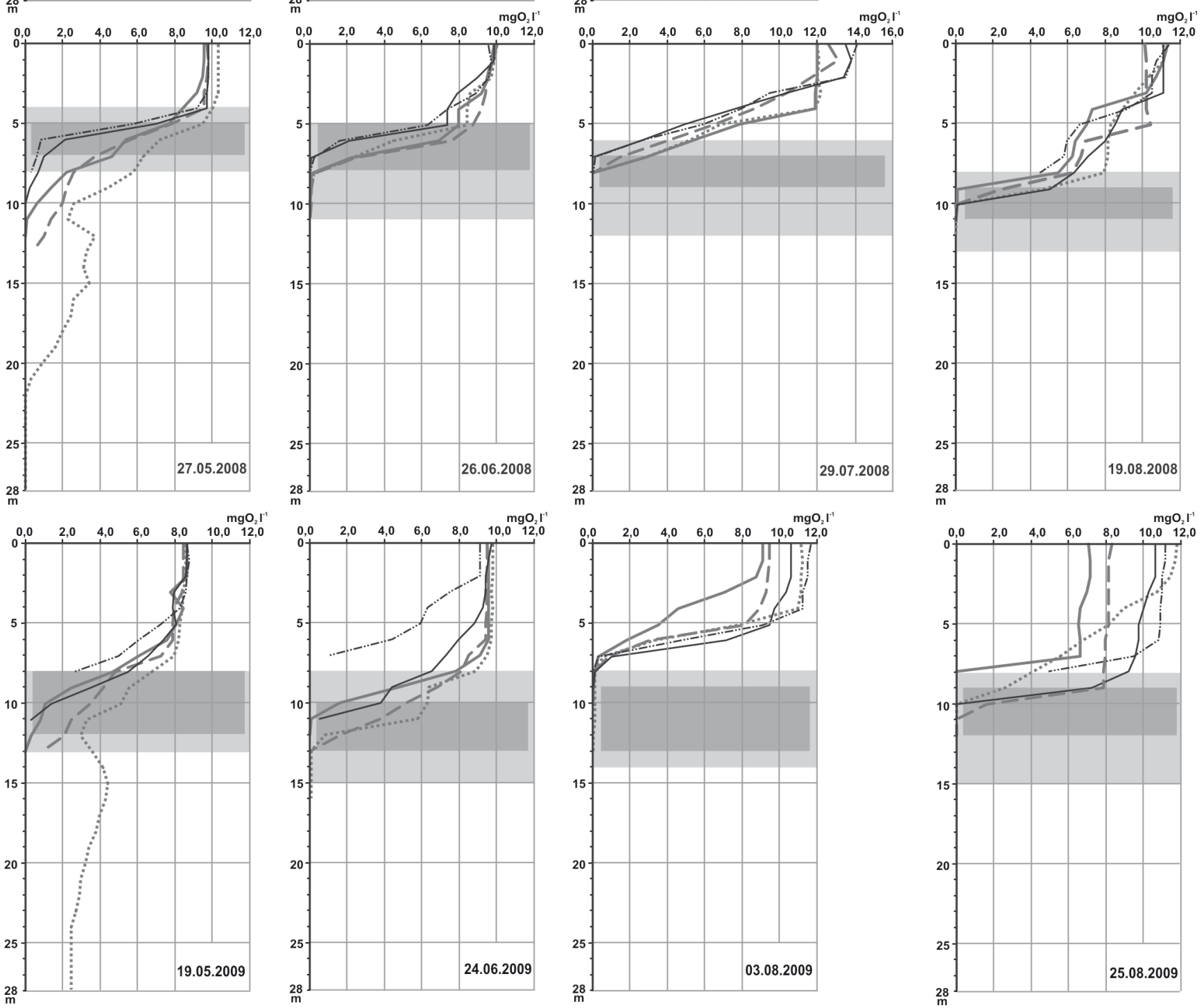

Fig. 6. Oxygen profiles of Lake Chełmżyńskie in the years 2007-2009: 1 - the extent of the metalimnion, 2 - the extent of maximum thermal gradients 

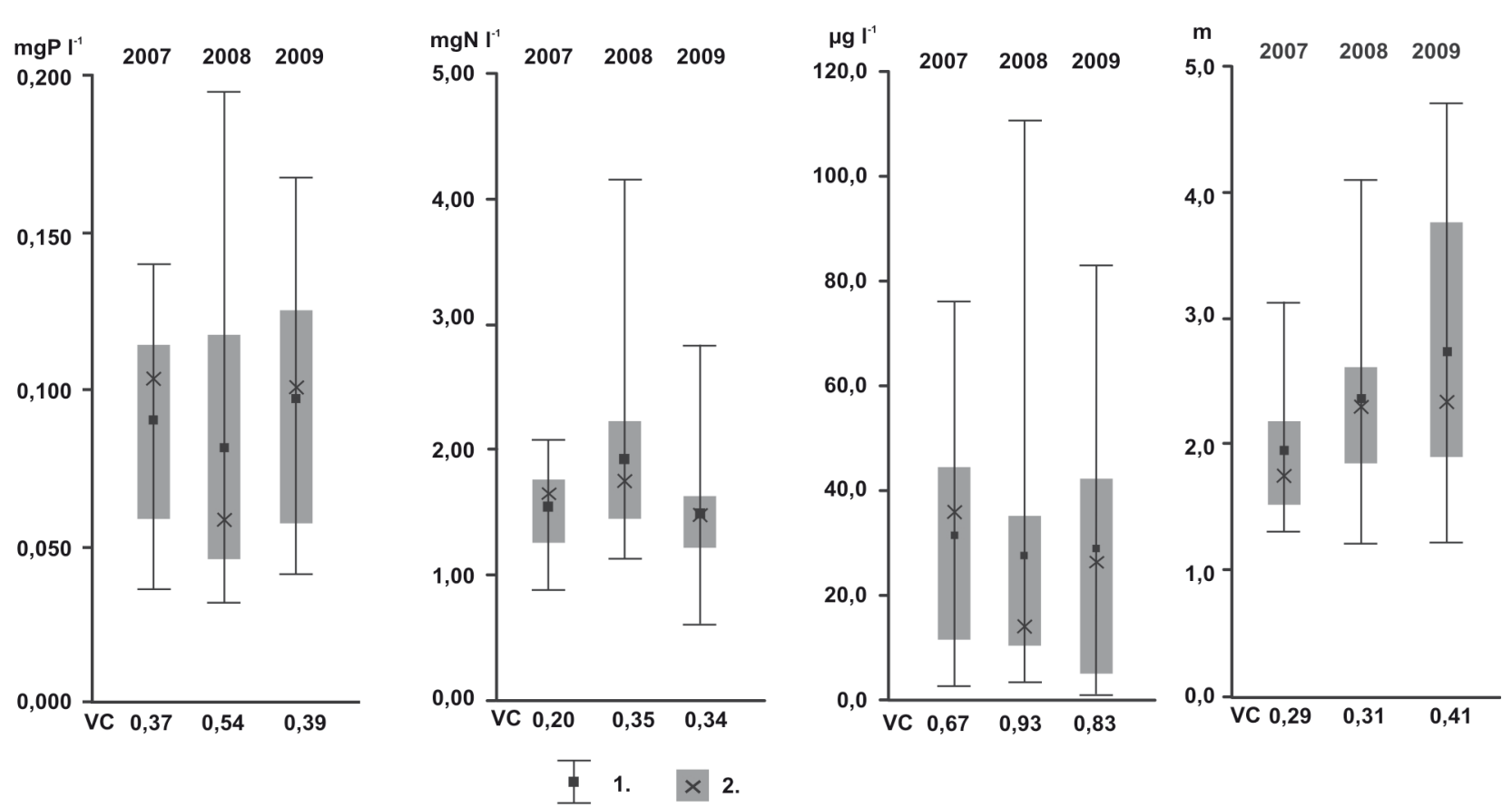

Fig. 7. Multi-year changeability of the visibility of the Secchi Disc and the concentrations of total phosphorus, total nitrogen, and chlorophyll $a$ in Lake Chełmżyńskie: 1 - mean and range, 2 - median, quartile 1 and 3, VC - variation coefficient

centration range of total phosphorus and phosphates in the final period of the summer stagnation (September) at the stand 1 amounted from 0.802 to 0.811 $\mathrm{mg} \mathrm{P} \mathrm{l}^{-1}$ and from 0.603 to $0.658 \mathrm{mg} \mathrm{P} \mathrm{l}^{-1}$ respectively. These values are nearly twice as high as the values recorded in three heated lakes in the vicinity of Konin: Mikorzyńskie, Licheńskie and Ślesińskie (Zdanowski et al. 2002; Stawecki et al. 2004). Similar concentrations of total phosphorus $\left(<0,5 \mathrm{mg} \mathrm{P} \mathrm{l}^{-1}\right)$ were also recorded in the near-bottom layer in nine deep mesoeutrophic and eutrophic lakes of the River Krutynia (Hillbricht-Ilkowska et al. 1996).

The concentrations of total nitrogen in the surface layer of the lake revealed a slightly lower seasonal variability. In 2007 variability coefficient amounted to 0.20 , while it exceeded the value of 0.30 in the remaining years (Fig. 7).

The mean concentration of chlorophyll $a$ in Lake Chełmżyńskie in the vegetation season was very similar in the particular years, and amounted from 28.4-31.4 $\mu \mathrm{g} \mathrm{l}^{-1}$. The smallest seasonal variability occurred in 2007 (the variability coefficient 0.67 ). The minimum concentrations of chlorophyll $a$ were marked in every season in the latter half of May, during the clear-water phase, and in October at the start of the autumn circulation. In the years 2007-2009 the recorded maximum value of chlorophyll $a$ amounted to $110.9 \mu \mathrm{g} \mathrm{l}^{-1}$ at the stand 1 (19.08.2008).

The multi-year range of the Secchi disc visibility during the clear-water phase at all the studied stands amounted from 2.4-3.1 m (2007) to 3.4-4.4 m (2009). The minimum values of the Secchi disc visibility measured in the years 2007-2009, and amounted 1.2 $-1.3 \mathrm{~m}$. The lowest water transparency was recorded during the spring circulation in the years 2007 and 2009 , and at the peak of the summer stagnation in the years 2008 and 2009.

The author found a strong statistical dependency between chlorophyll $a$ concentration and the Secchi disc visibility. The correlation coefficients $r$ were: 0.78 (2007), 0.90 (2008) and 0.87 (2009), at the level of statistical significance $p<0.001$.

The concentration of total phosphorus in the surface layer of Lake Chełmżyńskie showed considerable seasonal variability in the years 2007-2009 (Fig. 8). During the spring circulation noticeably higher concentrations of phosphorus were recorded in the years 2007 and 2009, while in 2008 the TP concentration was $0.036 \mathrm{mg} \mathrm{P} \mathrm{l}^{-1}$ on average. One of the reasons for such low concentration of phosphorus in the spring 2008 was the lack of the ice cover on Lake Chełmżyńskie. The mean air temperature val- 

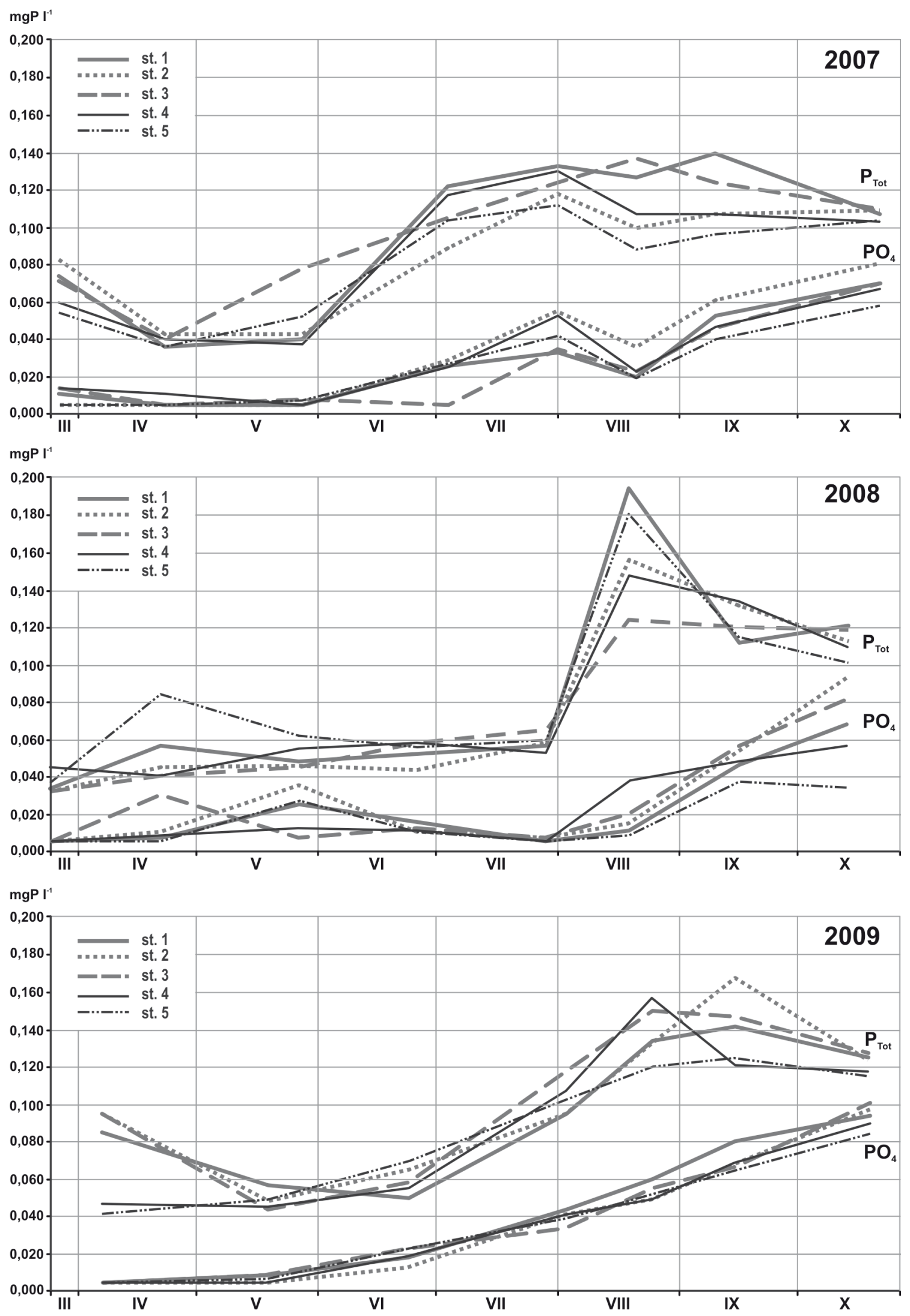

Fig. 8. Seasonal variability in phosphorus and phosphate concentrations in surface layer of Lake Chełmżyńskie in the years 2007-2009 

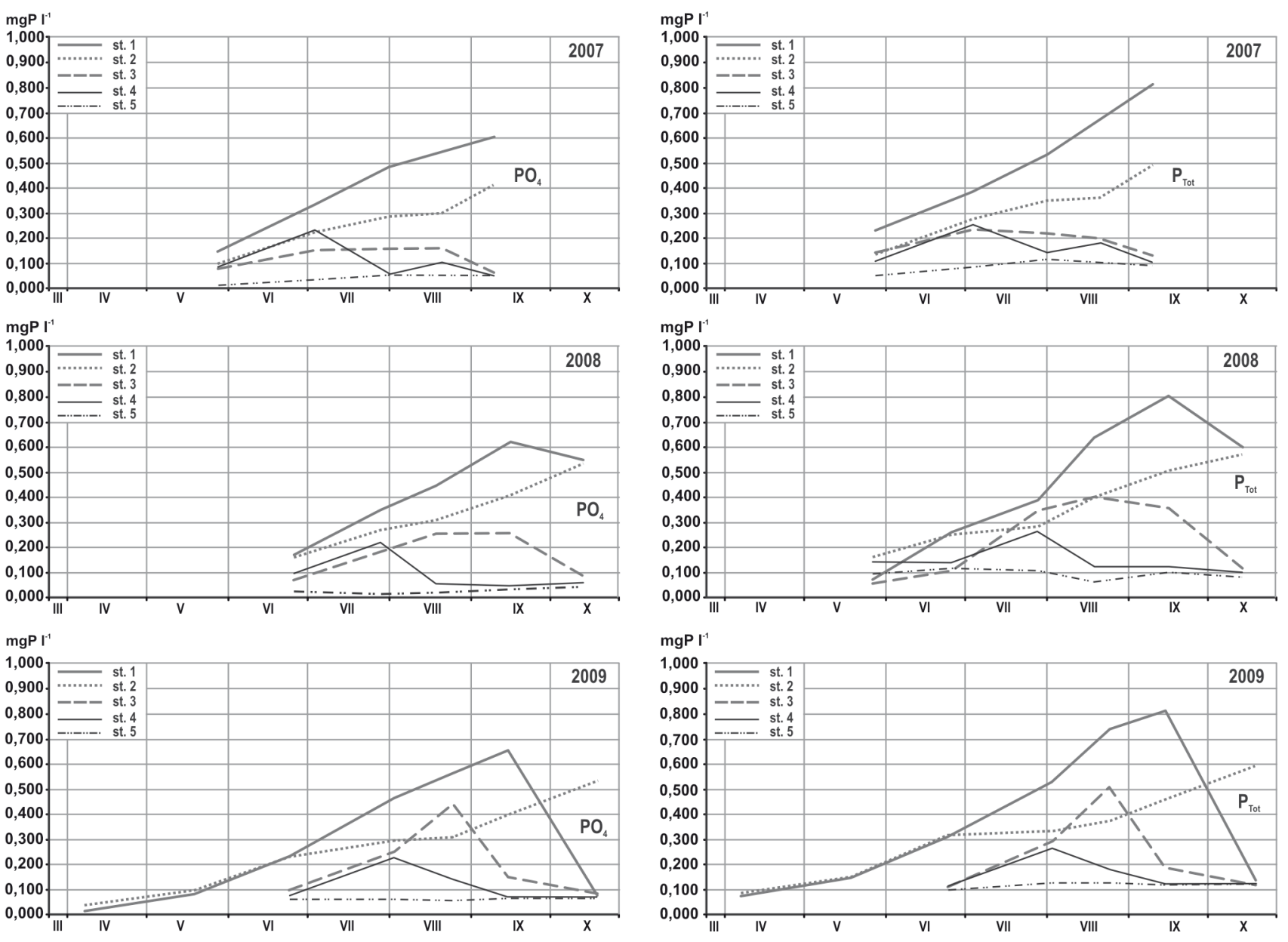

Fig. 9. Seasonal variability in phosphorus and phosphate concentrations in bottom layer of Lake Chełmżyńskie in the years 2007-2009

ues in January and February 2008 were positive, and equalled 1.1 and $3.6^{\circ} \mathrm{C}$ respectively (Kejna 2009). In such conditions, alongside the constant mixing of waters, the near-bottom layers are well oxygenated, and phosphorus is not released from the bottom deposits. A clear decline in phosphorus concentration in 2007 and 2008 may have resulted from the spring sedimentation of mineral and organic tryptone. As Kufel and Kalinowska (1997) proved with the reference to Lake Mikołajskie, $41 \%$ of the mean monthly concentration of molecular phosphorus in $20 \mathrm{~m}$ of the water column was eliminated during the spring sedimentation. In all the studied years the concentration of total phosphorus in the surface layer was very similar, and amounted to $0.050 \mathrm{mg} \mathrm{P} \mathrm{l}^{-1}$ on average during the clear-water phase (the latter half of May). At the end of May there were severe oxygen deficits at all the examination stands due to the mineralization of the falling tryptone. In 2007 and 2008 a deoxygen- ated zone appeared in the near-bottom layer at he stands 1 and 2. In such conditions the decomposition of iron-phosphorus complex and the release of phosphates to the near-bottom water occur (Cerco 1989). As early as in May the concentrations of phosphates and total phosphorus in the near-bottom layer were higher than the concentrations of phosphorus compounds in the surface layer. The pace of depletion of dissolved oxygen proceeded very fast in the lake, and anoxic conditions prevailed in the water layers within the metalimnion. In 2007 there was a really early and significant increase in phosphorus concentration in the surface layer of the lake, which resulted from the release of the internal loading of phosphorus (Fig. 8). The bottom deposits were the primary source of phosphorus in Lake Chełmżyńskie. The examinations conducted in July showed there was decline in phosphates in the near-bottom layer at the stands 3 and 4 (Fig. 9). The intense and deep mixis of waters caused by strong 
wind, whose mean daily velocity was $8.6 \mathrm{~m} \mathrm{~s}^{-1}$ on 27 th June, may have been the direct cause of such a phenomenon. The intensely blowing wind triggered the Lengmuir circulation. The sizes of cells in the lakes are confined by the depth of the epilimnion and usually reach up to $10 \mathrm{~m}$ (Imboden and Wuest 1995). According to McIntyre and Jellison (2001), wind velocities of 8-10 $\mathrm{m} \mathrm{s}^{-1}$ also generate downwelling and upwelling of the picnocline, enabling the transport of phosphorus compounds from the deoxygenated zone. In Lake Mono turbulent movements reached the depth of 9-10 m. The deepening of the epilimnion in Lake Chełmżyńskie and declining thermal gradients in the metalimnion resulted from the strong wind (Fig. 6). The mean total phosphorus concentration in the surface layer rose up to do $0.107 \mathrm{mg} \mathrm{P}^{-1}$ in July.

A similar phenomenon of the metalimnion erosion was described by Stawecki et al. (2003) with reference to Lake Wigry. It resulted in the increase in total phosphorus concentration in the epilimnion up to the mean value of $0.07 \mathrm{mg} \mathrm{P} \mathrm{l}^{-1}$ in August. According to Stawecki et al. (2003), the metalimnion became the main source of phosphorus due to the slight deepening of the epilimnion (approximately $1.0 \mathrm{~m}$ ). Gliwicz (1979) proved that accumulation and mineralisation of falling tryptone occurred in the metalimnion where thickness gradients were found.

The fertilization of the epilimnion waters with phosphates brought about the development of phytoplankton. A faster reaction of algae to the inflow of P-enriched waters during the erosion of the metalimnion was documented by Kortmann et al. (1982). A similar reaction of phytoplankton to the inflow of the hypolimnion waters was observed by Ostrovsky et al. (1996) in the laboratory conditions.

At other times of the examinations the mean total phosphorus concentration ranged from $0.107 \mathrm{mg}$ $\mathrm{P}^{-1}$ to $0.123 \mathrm{mg} \mathrm{P} \mathrm{l}^{-1}$. Simultaneously, there was a systematic increase in the portion of phosphates in the general pool of phosphorus, reaching the maximum in October (65\% on average). Slightly lower concentrations of total phosphorus and phosphates during the autumn circulation were recorded in Dejguny, an eutrophic lake (Dunalska et al. 2006).

In 2008 seasonal changes in the concentrations of total phosphorus in the surface layer of the lake occurred unlike in the year 2007 (Fig. 9). The mean concentration of total phosphorus ranged from 0.051 $0.059 \mathrm{mg} \mathrm{P} \mathrm{l}^{-1}$ in the months April - July. It must be noted that the wind blowing at the velocity of $6.5 \mathrm{~m} \mathrm{~s}^{-1}$ (24th July 2008) did not trigger the transport of phosphorus from the near-bottom layers. The violent increase in the concentration of phosphorus in the surface layers occurred as late as in August (Fig. 8). This phenomenon was also accompanied by the fast development of phytoplankton. The mean concentration of total phosphorus reached the value of $0.161 \mathrm{mg} \mathrm{P} \mathrm{l}^{-1}$. Similarly to early July 2007, the changes in 2008 were directly caused by the inflow of phosphates from the deoxygenated near-bottom layers of the lake. The examinations conducted at the end of July showed that the mean concentration of phosphates in the nearbottom layers at the stands $1-4$ amounted to $0.280 \mathrm{mg}$ $\mathrm{P}^{-1}$. The decline in the concentrations of phosphates at the stand 4 , and a smaller pace of their increase at the stand 3, indicate that the turbulent movements of water caused by the wind blowing at the velocity of 8.8 $\mathrm{m} \mathrm{s}^{-1}$ (5th August 2008) may have reached the depth of 10-12 m, and also deepened the epilimnion (Fig. 4). Intense mixing of waters caused by the winds blowing from the southwest and west direction. In September and October the concentration of total phosphorus in the surface layer fell down to $0.113-0.123 \mathrm{mg} \mathrm{P} \mathrm{l}^{-1}$, the values similar to those recorded at the same time in 2007.

Seasonal variability in the concentrations of total phosphorus in the near-bottom layer of the lake in 2009 was smaller as compared to the years 2007 and 2008 (Fig. 7). The minimum concentration of phosphorus was found in the clear-water phase. The subsequent investigations showed gradual increase in concentrations with the maximum value at the end of the summer stagnation (mean TP $0.140 \mathrm{mg} \mathrm{P}^{-1}$ ). Fairly strong winds (6.1-7.4 $\mathrm{m} \mathrm{s}^{-1}$ ) blowing in mid June (Fig. 3 ) did not cause considerable increase in the concentration of phosphorus in the surface layer. However, they brought about the decline of the maximum thermal gradient and the increase in the thickness of the metalimnion (Fig. 5). In the subsequent months the release of phosphates from the bottom deposits could have occurred in the lower epilimnion, particularly in early August as the concentration of dissolved oxygen at the depth of $8 \mathrm{~m}$ was $0.1 \mathrm{mg} \mathrm{O}_{2} \mathrm{l}^{-1}$ (Fig. 6). This rather small range of variability in the concentrations of phosphates at the particular stands may prove their gradual inflow from the near-bottom layers of the lake (Fig. 9). The occurrence of phosphates in the epilimnion and the ratio N/P $<15$ in August 2009 proved the limitation of primary production of phytoplankton by nitrogen. 
The increase in the concentration of phosphorus coming from the internal alimentation brought about intense development of phytoplankton. In the summer season in the years 2007 and 2008 Ceratium Hirundinella prevailed in the algae biomass (D. Lipińska-Winter pers. commun). The dependency between phosphorus and chlorophyll $a$ in the months March - September was of statistical significance during the study period 2007-2009 ( $p<0,001)$, and correlation coefficients were 0.79 in 2007, 0.89 in 2008, and 0.93 in 2009 . The strong dependency of phytoplankton production results from the fact that the phosphorus compounds released from the bottom deposits are biologically easily available (Kentzer 2001). On the other hand, the phosphorus coming from the river discharge (minimal in Lake Chełmżyńskie in the summer period) and the area runoff is generally absorbed on clayey and also humus particles, which are not directly taken by algae (Hillbricht-Ilkowska et al. 1996).

\section{Conclusion}

The investigations of the concentrations of phosphorus compounds in Lake Chełmżyńskie in the period 2007-2009 showed that the bottom deposits were their important source. The release of phosphates from the deposits took place with the depletion of dissolved oxygen, which regularly appeared in Lake Chełmżyńskie in the latter half of May. A particularly high concentration of phosphorus compounds was recorded in the southeast pool of the lake (st. 1). The probability of deep mixis occurring in the lake is illustrated by the low value of the Osgood Index, which equals 3.7. In addition, the deep mixis of the lake waters is favoured by the lack of a natural shield against wind activity. Particularly strong turbulent movements in the lake were set off by the winds blowing with the mean velocity of over $8.0 \mathrm{~m} \mathrm{~s}^{-1}$. Very strong winds in 2007 and 2008 or their lack in 2009 caused that the seasonal variability in phosphorus compounds in the surface layer happened in the studied period according to three different schemes. However, in every case the epilimnion waters were enriched with phosphates originating from the internal loading. The decline in the concentrations of phosphates in the near-bottom layer at the stand 3 and 4 in the months of July and August indicates that the central part of the lake is the main area from which phosphates are transported to the epilimnion layer.
The maximum concentrations of total phosphorus in the surface layer of Lake Chełmżyńskie were recorded in the summer period. The inflow of the internal loading of phosphates to the euphotic layer resulted in intense phytoplankton blooms.

According to the classification by Carlson (1977), the condition of Lake Chełmżyńskie corresponded to a severe eutrophic state in the years 2007-2009. Following the present guidelines of the Water Framework Directive the ecological condition of Lake Chełmżyńskie is seen as poor in the years 2007-2009. According to the Water Framework Directive, by 2015 the lakes of an area of over 50 ha should be of a good condition, at least. As Lake Chełmżyńskie does not meet the requirements of the Water Framework Directive, it should be included in the protection and restoration programmes. Due to a considerable influence of the internal loading of phosphorus upon the trophic and ecological condition of the lake, the inactivation of phosphates in the bottom deposits seems to be the right method of the lake restoration. The effectiveness of this method with respect to the lakes with various morphometric and hydrographic conditions was described in the works by Gawrońska, Łopata and Jaworska (2007).

The examinations of the thermal conditions of Lake Chełmżyńskie showed it had considerable dynamics of water mass, caused by its exposure to wind activity, among others. When strong winds appear intense turbulent movements favour the transport of phosphorus from the near-bottom water layers. Therefore, the development of natural barriers in the form of wide trees and bushes, particularly along the south and southwest shore should be considered. This would certainly restrain the influence of winds. The proposed actions may cause changes in the water mixis of Lake Chełmżyńskie in the long run, and eventually reduce the transport of phosphates from the near-bottom layers, particularly in the central part of the lake.

\section{Acknowledgements}

The author would like to thank dr. hab. Marek Kejna and dr Joanna Uscka-Kowalkowska for offering meteorological data, and would also like to express his gratitude to the Colleagues from the Laboratory of the Torun Branch headed by Ms Elżbieta Kowalska and Ms Danuta Lipińska-Winter for carrying out the chemical and hydrobiological analyses, and Mr Sławomir Śliwiński for his help in the field investigations. 


\section{References}

Carlson R.E., 1977, A trophic state index for lakes, Limnol. Oceanogr. 22(2): 366-369.

Cerco C.F., 1989, Measured and modeled effects temperature, dissolved oxygen and nutrient concentration on sediment-water nutrient exchange, Hydrobiologia 174 (3): 185-194.

Cooke G.D., Welch E.B., Peterson S.A., Newroth P.R., 1993, Restoration and management of lakes and reservoirs, Lewis Publishers, Boca Raton, p. 548.

Dunalska J., Brzozowska R., Zdanowski B., Stawecki K., Pyka J., 2006, Variability of Organic Carbon, Nitrogen and Phosphorus in the Context of Lake Dejguny Eutrophication (Mazurskie Lakes District), Limnol. Rev. 6: 79-86.

Gawrońska H., Łopata M., Jaworska B., 2007, The effectiveness of the phosphorus inactivation method in reducing the trophy of lakes of different morphometric and hydrological features, Limnol. Rev. 7(1): 27-34.

Gliwicz Z.M., 1979, Metalimnetic gradients and trophic state of lake epilimnia, Mem. Ist. Ital. Idrobiol. 37: 121143.

Hillbricht-Ilkowska A., Kostrzewska-Szlakowska I., Wiśniewski R.J., 1996, Zróżnicowanie troficzne jezior rzeki Krutyni (Pojezierze Mazurskie) - stan obecny, zmienność wieloletnia, zależności troficzne (Trophic differentiation of lakes along river Krutynia (Mazurian Lakeland) - present situation, long-term variability and trophic relationships), [in:] A. Hillbricht-Ilkowska, R.J. Wiśniewski (eds), Funkcjonowanie systemów rzeczno-jeziornych w krajobrazie pojeziernym: rzeka Krutynia (Pojezierze Mazurskie) (The functioning of river-lake system in a lakeland landscape: river Krutynia (Mazurian Lakeland, Poland), Zesz. Nauk. Komitetu „Człowiek i Środowisko” PAN 13: 125-153 (in Polish, English summary).

Imboden D.M., Wuest A., 1995, Mixing mechanisms in lakes, [in:] A. Lerman, D. Imboden, J.Gat (eds), Physics and chemistry in lakes, Springer-Verlag, Berlin-Heidelberg: 83-137.

Jureko L., 1969, Przyczyny zanikania Jeziora Chełmżyńskiego w świetle bilansu jego zlewni (Causes of the Chełmżynskie Lake decline considering its basin budget), Pr. PIHM 96: 93-106 (in Polish, English summary).

Kajak Z., 1998, Hydrobiologia - limnologia. Ekosystemy wód śródlądowych (Hydrobiology - limnology. Freshwater ecosystems), Wyd. Nauk. PWN, p. 355 (in Polish).

Kejna M., 2008, Zintegrowany monitoring środowiska przyrodniczego - Stacja Koniczynka (The Integrated Natural Environment Monitoring - Station Koniczynka), [in:] E. Jutrowska (ed.), Raport o stanie środowiska województwa kujawsko-pomorskiego w 2007 roku (The Report on the state of the environment in the Kujawsko-Pomorskie Voivodeship in 2007), Bibl. Monit. Środ., Bydgoszcz: 183-190 (in Polish).
Kejna M., 2009, Zintegrowany monitoring środowiska przyrodniczego - Stacja Koniczynka (The Integrated Natural Environment Monitoring - Station Koniczynka), [in:] E. Jutrowska (ed.), Raport o stanie środowiska województwa kujawsko-pomorskiego w 2008 roku (The Report on the state of the environment in the Kujawsko-Pomorskie Voivodeship in 2008), Bibl. Monit. Środ., Bydgoszcz: 169-175 (in Polish).

Kentzer A., 2001, Fosfor i jego biologicznie dostępne frakcje w osadach jezior różnej trofii (Phosphorus and its biologically available fractions in the bottom deposits in the lakes with different trophic states), Wyd. UMK, Toruń, p. 111 (in Polish).

Kortmann R.W., Henry D.D., Kuether A., Kaufman S., 1982, Epilimnetic nutrient loading by metalimnetic erosion and resultant algal responses in Lake Waramaug, Connecticut, Hydrobiologia 92: 502 (abstract).

Kudelska D. Cydzik D., Soszka H., 1994, Wytyczne monitoringu podstawowego jezior (Guidelines for basic monitoring of the lakes), Bibl. Monit. Środ., PIOŚ, Warszawa, p. 42 (in Polish).

Kufel L., Kalinowska K, 1997, Metalimnetic gradients and the vertical distribution of phosphorus in a eutrophic lake, Arch. Hydrobiol. 140(3): 309-320.

Lampert W., Sommer U., 2001, Ekologia wód śródlądowych (Ecology of inland waters), Wyd. Nauk. PWN, Warszawa, p. 415 (in Polish).

Lorke A., Wuest A., 2005, Turbulence and mixing regimes specific to lakes, [in:] H.Z. Baumert, J. Simpson, J. Sundermann (eds), Marine turbulance: theories, observations, and models. Results of CARTUM Project, Cambridge University Press, Cambridge: 346-354.

Marszelewski W., 1998, Gospodarcze wykorzystanie jezior Pojezierza Chełmińsko-Dobrzyńskiego i Kujawskiego przez przemysł cukrowniczy (Economic exploitation of the lakes located in the Chełmińsko-Dobrzyńskie and Kujawskie Lakeland by sugar plants, [in:] W. Lange, D. Borowiak (eds), Zagrożenia degradacyjne a ochrona jezior (Degradation hazards and lakes protection), Wyd. KLUG, Gdańsk: 203-212 (in Polish).

McIntyre S., Jellison R., 2001, Nutrient fluxes from upwelling and enhanced turbulence at the top of the pycnocline in Mono Lake, California, Hydrobiologia 466: 13-29.

Niewiarowski W., 1959, Formy polodowcowe i typy deglacjacji na Wysoczyźnie Chełmińskiej (Glacial forms and types of deglaciations on the moraine plateau of Chełmno), Stud. Soc. Scien. Torun., Sec. C 4(1): 1-170 (in Polish, English summary).

Nurnberg G. K.,1994, Phosphorus release from anoxic sediments: What we know and how we can deal with it, Limnetica 10(1): 1-4.

Osgood R.A. 1988, Lake mixis and internal phosphorus dynamics, Arch. Hydrobiol. 113: 629-638.

Ostrovsky I., Yacobi Y.Z., Walline P., Kalikhman I, 1996, Seiche-induced mixing: Its impact on lake productivity, Limnol. Oceanogr. 41(2): 323-332. 
Pasławski Z., 1975, Typologia hydrologiczna jezior Pojezierza Wielkopolskiego (Hydrological types of the lakes located in the Wielkopolskie Lakeland), Prz. Geof. 20 (4): 271-280 (in Polish, English summary).

[WIOŚ] Wojewódzki Inspektorat Ochrony Środowiska w Bydgoszczy, 2008, Raport o stanie środowiska województwa kujawsko-pomorskiego w 2007 roku (The Report on the state of the environment in the KujawskoPomorskie Voivodeship in 2007), Bibl. Monit. Środ. Bydgoszcz, p. 230 (in Polish).

[WIOŚ] Wojewódzki Inspektorat Ochrony Środowiska w Bydgoszczy, 2009, Raport o stanie środowiska województwa kujawsko-pomorskiego w 2008 roku (The Report on the state of the environment in the KujawskoPomorskie Voivodeship in 2008), Bibl. Monit. Środ. Bydgoszcz, p. 204 (in Polish).

Stawecki K., Zdanowski B., Dunalska J., 2003, Seasonal changes in phosphorus concentrations in the waters of Lake Wigry, Limnol. Rev. 3: 217-222.
Stawecki K., Zdanowski B., Dunalska J., 2004, Seasonal changes in phosphorus concentration in the heated waters of Lake Mikorzyńskie, Limnol. Rev. 4: 249-254.

Wetzel R.G., 2001, Limnology. Lake and river ecosystems, Academic Press, San Diego, p.1006.

Wiśniewski R, 1995, Rola resuspensji osadów dennych w funkcjonowaniu ekosystemów wodnych (The role of re-suspension of bottom deposits in water ecosystems functioning), UMK Toruń, p.102 (in Polish, English summary).

Wiśniewski R.J., 1995, Rola zasilania wewnętrznego w eutrofizacji zbiorników zaporowych (The role of internal loading in dam reservoir eutrophication) [in:] M. Zalewski (ed.), Procesy biologiczne w ochronie i rekultywacji nizinnych zbiorników zaporowych (Biological processes in the protection and reclamation of the lowland dam reservoirs), Bibl. Monit. Środ., Łódź: 61-70 (in Polish).

Zdanowski B., Dunalska J., Stawecki K., 2002, Variability of nutrients content in heated lakes of the Konin area, Limnol. Rev. 2: 457-464. 